\title{
Morphological Changes of Salicylic Acid Application on Pepper (Capsicum annuum L.) Seedling under Cold Condition
}

\author{
Mohammed Ahmed Ahmed ${ }^{1}$, M. Zeki Karipçin (D) 1,* , Fikret Yaşar² $^{2}$ \\ ${ }^{1}$ Department of Horticulture, Faculty of Agriculture, Siirt University, Siirt, Turkey \\ ${ }^{2}$ Department of Horticulture, Faculty of Agriculture, Yüzüncü Y1l University, Van, Turkey
}

\begin{abstract}
This project was developed to investigate the contribution of salicylic acid (SA) to the development of pepper seedlings grown in low temperature $\left(0^{\circ} \mathrm{C}\right)$ conditions. The research was carried out in the controlled plant growing cabinet in the research- investigation area of the Department of Horticulture, Faculty of Agriculture, Siirt University. As a vegetable material, Urartu F1 pepper type (capia) which is used in greenhouse cultivation has been used. As a dose of different salicylic acid; 0.01 and 0.05 mmol doses were applied. The dose of $0 \mathrm{mmol}$ salicylic acid was used as a control group. Application frequency; It was applied 1 time, 2 times and 3 times. 3 different cold application times were also investigated; 24 hours, 48 hours and 72 hours. The experiment was designed in randomized plots and 3 replications. In the pepper seedlings Rate of Lost Seedling Weight (ROLSW) and Rate of Lost Seedling Length (ROLSL) were investigated. At the end of the research; Both SA applications increased the ROLSW rate according to the control. The application of $0.01 \mathrm{ppm}$ was the SA application with the highest ROLSW rate. The application of $0.01 \mathrm{ppm}$ SA also increased the ROLSL rate compared to the control. The highest ROLSW and ROLSL rates were obtained from 24-hour cold application. There was no statistically significant difference between the frequencies of application.
\end{abstract}

\section{ARTICLE HISTORY}

Received: April 27, 2019

Revised: November 16, 2019

Accepted: December 16, 2019

\section{KEYWORDS}

Abiotic stress,

Salicylic acid,

Pepper,

Cold damage

\section{INTRODUCTION}

Temperature is a major factor in abiotic stress and to determine agricultural productivity and crop productivity. The rate is reduced and the amount of absorption of water and nutrients from cold stress, leading to cell drying and starvation and called extreme forms of cold stress stresses frozen and cause the formation of ice in the cell fluid, which leads to dehydration and death in plants. The low temperature (LT) is the environmental stress that affects crop production and quality. Regulates the expression of several proteins, metabolites and many genes [1].

Pepper plants are initially from tropic areas and require high-temperature conditions for their advancement. Subsequently, the ideal development temperature is in the vicinity of 25 and $30{ }^{\circ} \mathrm{C}$, such that temperature changes influence an assortment of physiological capacities and

CONTACT: Zeki Karipçin $₫$ zkaripcin@gmail.com $\equiv$ Department of Horticulture, Faculty of Agriculture, Siirt University, Siirt, Turkey 
morphological improvement. At the point when temperature diminishes underneath $15{ }^{\circ} \mathrm{C}$, pepper development is decreased, and sprout and organic product generation stop [2].

Salicylic acid's activities incorporate practicing a thermogenic impact [3], expanding thermotolerance [4], empowering extrinsic root arrangement [5], demonstrating herbicides impact [6], lessening leaf shed [7], giving protection against pathogens [8], manages ethylene biosynthesis [9-10] and changing the quality and amount of proteins [11]. It has been asserted [12] that SA and comparative phenolic mixes practice their impact of giving protection against various anxiety factors in plants corrosive [13] and cytokinins [12]. These perceptions and reports on numerous other physiological impacts achieved by SA conjured in a few scientists this substance may be another plant development controller [14]. The experiment was designed to study the effect of different concentrations of salicylic acid on resistance to low temperature. The aim of this study to find out the answer to these questions; which morphological changes occur at different low-temperature periods. And just how do doses of salicylic acid effect at cold condition on pepper seedlings' morphological features?

\section{MATERIAL and METHODS}

This study was carried out in the horticulture department, agriculture faculty of Siirt University in 2018. Siirt is a province and located between the $41^{\circ}-57^{\circ}$ East longitude and $37^{\circ}$ $-55^{\circ}$ northern latitudes in as its geographical location. In Siirt province, it dominates the continental climate which is the most important feature of the four seasons, continental climate prevails. The summers are hot and arid, with no precipitation in June and October [15].

\subsection{Plant Materials}

A capia pepper variety (Urartu F1) was used for plant material. This pepper variety could be grown at the cool climate in the greenhouse. Pepper seedlings were grown at a growing chamber.

\subsection{Methods}

$0.01 \mathrm{mmol}, 0.05 \mathrm{mmol}$, and $0 \mathrm{mmol}$ doses of salicylic acid were applicated before applying cold stress. For control groups only distilled water was applicated each time. After 0 ${ }^{0} \mathrm{C}$ temperature application; did cold application create a non-irreversible wilting to seedlings, do all seedlings' have cold damage on their leaves and stems? Are there differences in seedlings weight and lengths? Also, salicylic acid was 1, 2 and 3 times applicated for each dose. Polysorbate [16] (Twin 20) was also used enough quantity for adhesive. For easier penetration of salicylic acid thin holes in the leaves were made by small needles.

\subsubsection{Seedling Weight (gr)}

Before and after cold application, 5 randomly seedlings per application were selected and then measured by scale sensitive to $0.01 \mathrm{~g}$ (Figure 1).
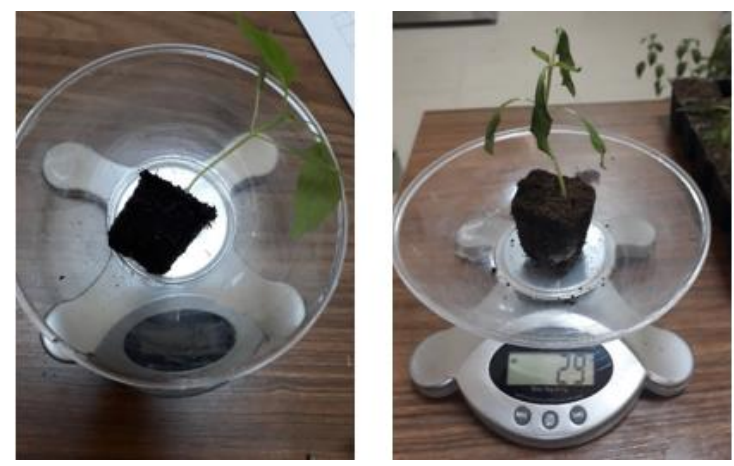

Figure 1. Seedling weight (before and after) application 


\subsubsection{Seedling length (cm)}

5 seedlings per applications were randomly selected. The distance from the soil surface to the seedling's top was measured for each seedling by a ruler. All measurements were performed before and after the cold application (Figure 2).
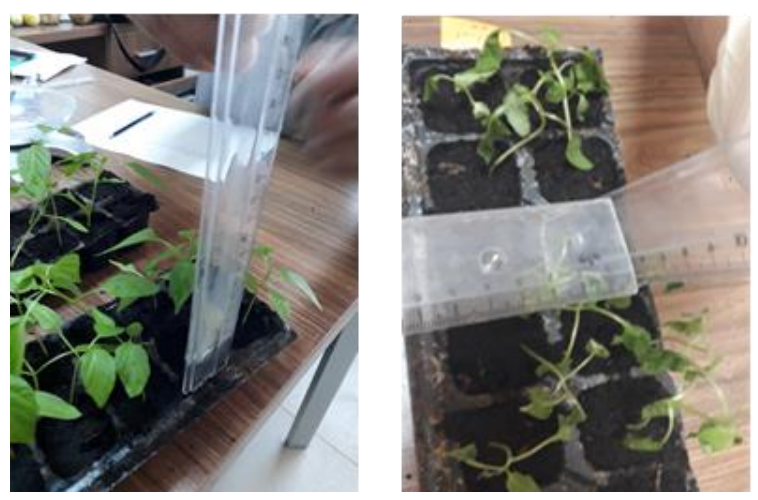

Figure 2. Seedling length (before and after) application

\subsubsection{Experimental Design}

The experimental design used was a Randomized Complete Parcel Design (RCPD) with factorial. The treatment in each experiment had three replicates. Where was statistically analyze the data and compared means using "LSD"s Multiple Range Test at 0.05 and 0.01 levels.

\section{RESULTS and DISCUSSION}

The differences between the doses to Least Square (Sq.) Mean was significant. Least Sq. Mean of ROLSW ranged between -46.0 - - 63.1 percent. The average Least Sq. Mean of doses was $-52.0 \%$. The highest Least Sq. Mean value of ROLSW was obtained from $0.01 \mathrm{mmol}$ dose as $-46.0 \%$, and the lowest ROLSW's Mean value was obtained from the control concentration of salicylic acid as $-63.1 \%$. The highest Least Sq. Mean value was obtained from frequency 1 as $-47.8 \%$, and the lowest Least Sq. Mean value was obtained from frequency 2 as $-54.3 \%$. The highest Mean of doses value of ROLSL was determined from $0.01 \mathrm{mmol}$ dose as $-52.0 \%$ (Table 1).

Table 1. Effect of Doses, Time and Application Frequency of Salicylic Acid

\begin{tabular}{|c|c|c|c|c|c|c|c|c|c|c|c|c|}
\hline & \multicolumn{3}{|c|}{ Doses (ppm) } & \multirow[t]{2}{*}{ Mean } & \multicolumn{3}{|c|}{ Time (hour) } & \multirow[t]{2}{*}{ Mean } & \multicolumn{3}{|c|}{ Frequency (times) } & \multirow[t]{2}{*}{ Mean } \\
\hline & 0.01 & 0.05 & Con. & & 24 & 48 & 72 & & 1 & 2 & 3 & \\
\hline ROLSW & $\begin{array}{l}\tilde{\sigma} \\
\stackrel{0}{0} \\
\dot{0} \\
\dot{+}\end{array}$ & 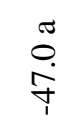 & $\frac{0}{\overrightarrow{0}}$ & $\begin{array}{l}0 \\
\text { in } \\
\text { î }\end{array}$ & $\begin{array}{l}\pi \\
\infty \\
\stackrel{\infty}{~} \\
\stackrel{1}{1}\end{array}$ & $\begin{array}{l}0 \\
\hat{\sigma} \\
\hat{\sigma}\end{array}$ & $\begin{array}{l}0 \\
0 \\
\dot{T} \\
\end{array}$ & 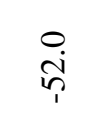 & $\begin{array}{l}\widetilde{\sigma} \\
\infty \\
\stackrel{+}{+}\end{array}$ & $\begin{array}{l}\underset{n}{m} \\
\stackrel{\sim}{*}\end{array}$ & $\frac{\varpi}{\stackrel{\sim}{\sim}}$ & 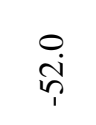 \\
\hline ROLSL & $\begin{array}{l}\tilde{\sigma} \\
\text { ì } \\
\text { î. }\end{array}$ & $\begin{array}{l}\text { है } \\
0 \\
0 \\
i\end{array}$ & $\begin{array}{l}0 \\
\dot{v} \\
\dot{v} \\
1\end{array}$ & $\begin{array}{l}\infty \\
\infty \\
\infty \\
\sim\end{array}$ & 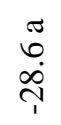 & 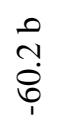 & \begin{tabular}{l}
0 \\
0 \\
\multirow{1}{\infty}{} \\
1
\end{tabular} & 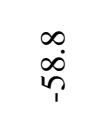 & $\begin{array}{l}\stackrel{\sigma}{+} \\
\underset{\sim}{\infty} \\
\stackrel{\infty}{r}\end{array}$ & $\frac{\pi}{n}$ & $\begin{array}{l}\tilde{\pi} \\
\text { N̦} \\
\stackrel{0}{0}\end{array}$ & $\begin{array}{l}\infty \\
\infty \\
\infty \\
i\end{array}$ \\
\hline
\end{tabular}

ROLSW: Rate of Lost Seedling Weight, ROLSL: Rate of Lost Seedling length

The best value (-28.6\%) belong to 24-hour application in the ROLSL mean values. Three and two time frequency values have the same statistical group as the best frequency application (respectively $-60.2 \%$ and $-57.9 \%$ ) for ROLSL (Table 1). 
According to the Interaction of Time, doses and Frequency of salicylic acid; the highest Least Sq. Mean of ROLWS values were obtained from frequency 2 and time $24 \mathrm{~h}$ as $-10.9 \%$, and the lowest Least Sq. Mean values was obtained from frequency 2 and time $72 \mathrm{~h}$ as $-80.5 \%$. When the first three results are observed, $24 \mathrm{~h}$ applications was the best result and very different from the other applications. The highest Least Sq. Mean of ROLWS values was obtained from frequency 1 and dose $0.01 \mathrm{mmol}$ as $-41.4 \%$, and the lowest Least Sq. Mean values was obtained from frequency 3 and control dose as $-67.2 \%$. The differences between the frequencies, doses and times for Least Sq. Mean was significant. Least Sq. Mean ranged between $-9.84--96.50$ percent at Time $x$ Doses $x$ Frequency interaction of ROLWS. The average Least Sq. Mean of frequencies and doses and times was $-52.02 \%$. The highest Least Sq. Mean values was obtained from frequency 2 and control dose and time $24 \mathrm{~h}$ as $-9.84 \%$, and the lowest Least Sq. Mean values was obtained from frequency 3 and control doses and time $48 \mathrm{~h}$ as $-96.50 \%$. In the Time $\mathrm{x}$ Doses interaction of ROLWS; the highest value was obtained from $24 \mathrm{~h}$ and dose $0.05 \mathrm{mmol}$ interaction as $-12.8 \%$, and the lowest Least Sq. Mean values was obtained from time $48 \mathrm{~h}$ and control dose as $-92.80 \%$. (Table 2).

At the frequency x Time interaction of ROLSL; the differences between the frequencies and times to Least Sq. Mean were significant. The average Least Sq. Mean of frequencies and times was $-58.8 \%$. The highest Least Sq. Mean values was obtained from frequency 2 and time $24 \mathrm{~h}$ as $-24.6 \%$, and the lowest Least Sq. Mean values was obtained from frequency 2 and time $72 \mathrm{~h}$ as $-89.1 \%$. It has been clearly observed that the first three results, $24 \mathrm{~h}$ applications was the best result and very different from the other applications, while the last three results have the worst results. Least Sq. Mean of the frequencies and the doses was significant; least Sq. Mean ranged between $-43.8--68.8$ percent. The average Least Sq. Mean of frequencies and doses were $-58.8 \%$. The highest Least Sq. Mean values was obtained from frequencies 1 and dose $0.01 \mathrm{mmol}$ as $-43.80 \%$, and the lowest Least Sq. Mean values was obtained from frequency 2 and control dose as $-68.8 \%$. At the point when watched the initial three outcomes, and two of the concentration at $0.01 \mathrm{mmol}$ and one of the other at $0.05 \mathrm{mmol}$ applications were the best outcome and altogether different from other applications. While the last three outcomes have fewer outcomes. The average Least Sq. Mean of frequencies and doses and times of ROLSL was $-58.79 \%$. The highest Least Sq. Mean values was obtained from frequency 1 and dose $0.01 \mathrm{mmol}$ and time $48 \mathrm{~h}$ as $-19.31 \%$, and the lowest Least Sq. Mean values was obtained from frequency 2 and control dose and time $72 \mathrm{~h}-95.65$. The highest Least Sq. Mean value of ROLSL was obtained from time $24 \mathrm{~h}$ and control dose as $-21.2 \%$, and the lowest Least Sq. Mean values was obtained from time $72 \mathrm{~h}$ and control dose as $-92.6 \%$.

Processing the pepper seedlings with salicylic acid for 16 hours, the results obtained, it was the negative effect on fresh weight increase, and dry weight increase in the application 5and 10-mM SA. The result is different from this study because the times used are different from each other's (24, 48 and 72 hours in the test) [17]. In winter wheat leaves grow at low temperatures. It is sprayed with salicylic acid, the influence of external factors decreased and also the decreased freezing injury [18]. Salicylic acid sprinkled on coriander plant with at concentrations of 20 and $35 \mathrm{mg} / \mathrm{L}$. got results on the significant increase in the soft weight of the vegetative group, and the number of flowers inflorescences, and the number of seeds per inflorescence, and weight 100 seed and production of the plant seeds [19]. It could be recommended that foliar spraying with salicylic acid at $100 \mathrm{ppm}$, to increase the final yield and fruit quality of sweet pepper plant during the low temperatures of autumn plantations [20]. The researcher found [21] the effect of salicylic acid on macrophomina and the evolution of fever disease on the Sun Flower plant. Results experience recommended that all pots concentrations may be affected significantly in reducing the percentage of injury. As for the concentrations of 200 and $250 \mathrm{mg} / \mathrm{L}$ salicylic acid effect of the dry weight increase total of vegetables and also an increase in the dry weight total of the roots. The study indicated that high concentrations of 
Table 2. Effect of Interaction of Time, Doses and Frequency of Salicylic Acid

\begin{tabular}{|c|c|c|c|c|c|c|c|}
\hline & Interaction & ROLWS & ROLSL & & Interaction & ROLWS & ROLSL \\
\hline \multirow{10}{*}{$\begin{array}{l}\text { Time } \mathrm{x} \\
\text { Doses }\end{array}$} & $24 \times 0,01$ & $-14.9 \mathrm{a}$ & $-24.3 \mathrm{a}$ & Time $\mathrm{x}$ & $1 \times 0,01 \times 24$ & $-21.61 \mathrm{a}$ & $-27.05 a b$ \\
\hline & $24 \times 0,05$ & $-12.8 \mathrm{a}$ & $-40.4 b$ & $\begin{array}{c}\text { Doses X } \\
\text { Frequency }\end{array}$ & $1 \times 0,05 \times 24$ & $-14.16 \mathrm{a}$ & $-40.33 \mathrm{a}-\mathrm{d}$ \\
\hline & 24 x Con. & $-13.7 \mathrm{a}$ & $-21.2 \mathrm{a}$ & & 1 x Con. X 24 & $-16.20 \mathrm{a}$ & $-21.86 a b$ \\
\hline & $48 \times 0,01$ & $-51.5 b$ & $-41.4 b$ & & $2 \times 0,01 \times 24$ & $-12.40 \mathrm{a}$ & $-23.28 a b$ \\
\hline & $48 \times 0,05$ & $-58.5 b c$ & $-56.8 c$ & & $2 \times 0,05 \times 24$ & $-10.71 \mathrm{a}$ & $-28.21 a-c$ \\
\hline & $48 \times$ Con. & $-92.8 \mathrm{e}$ & $-82.4 \mathrm{~d}$ & & $2 \times$ Con. $x 24$ & $-9.84 \mathrm{a}$ & $-22.27 \mathrm{ab}$ \\
\hline & $72 \times 0,01$ & $-71.6 \mathrm{~cd}$ & $-90.2 d$ & & $3 \times 0,01 \times 24$ & $-10.57 \mathrm{a}$ & $-22.46 a b$ \\
\hline & $72 \times 0,05$ & $-69.7 \mathrm{~cd}$ & $-79.9 \mathrm{~d}$ & & $3 \times 0,05 \times 24$ & $-13.56 \mathrm{a}$ & $-52.53 \mathrm{c}-\mathrm{g}$ \\
\hline & $72 \times$ Con. & $-82.8 \mathrm{de}$ & $-92.6 \mathrm{~d}$ & & 3 x Con. $x 24$ & $-15.18 \mathrm{a}$ & $-19.43 \mathrm{a}$ \\
\hline & Mean & -52.0 & -58.8 & & $1 \times 0,01 \times 48$ & $-23.01 \mathrm{a}$ & $-19.31 \mathrm{a}$ \\
\hline \multirow{10}{*}{$\begin{array}{l}\text { Frequency } \\
\text { x Time }\end{array}$} & $1 \times 24$ & $-17.3 \mathrm{a}$ & $-29.8 \mathrm{a}$ & & $1 \times 0,05 \times 48$ & $-66.60 b-e$ & $-68.71 \mathrm{e}-\mathrm{i}$ \\
\hline & $1 \times 48$ & $-58.8 b$ & $-58.8 b$ & & $1 \times$ Con. $\mathrm{x} 48$ & $-86.87 \mathrm{~d}-\mathrm{f}$ & $-88.43 \mathrm{i}-\mathrm{k}$ \\
\hline & $1 \times 72$ & $-66.9 b c$ & $-86.5 c$ & & $2 \times 0,01 \times 48$ & $-65.86 b-e$ & $-44.75 b-e$ \\
\hline & $2 \times 24$ & $-10.9 \mathrm{a}$ & $-24.6 \mathrm{a}$ & & $2 \times 0,05 \times 48$ & $-53.43 b$ & $-46.46 b-f$ \\
\hline & $2 \times 48$ & $-71.4 \mathrm{bc}$ & $-59.9 b$ & & $2 \times$ Con. $x 48$ & $-95.04 \mathrm{f}$ & $-88.46 \mathrm{i}-\mathrm{k}$ \\
\hline & $2 \times 72$ & $-80.5 c$ & $-89.1 \mathrm{c}$ & & $3 \times 0,01 \times 48$ & $-65.69 b-e$ & $-60.26 d-h$ \\
\hline & $3 \times 24$ & $-13.1 \mathrm{a}$ & $-31.5 \mathrm{a}$ & & $3 \times 0,05 \times 48$ & -55.32 bc & $-55.28 \mathrm{~d}-\mathrm{g}$ \\
\hline & $3 \times 48$ & $-72.5 b c$ & $-61.9 b$ & & $3 \times$ Con. $x 48$ & $-96.50 \mathrm{f}$ & $-70.19 f-j$ \\
\hline & $3 \times 72$ & $-76.5 c$ & $-87.1 c$ & & $1 \times 0,01 \times 72$ & $-79.44 c-f$ & $-85.03 \mathrm{~h}-\mathrm{k}$ \\
\hline & Mean & -52.0 & -58.8 & & $1 \times 0,05 \times 72$ & $-58.60 \mathrm{bc}$ & -83.64 h-k \\
\hline \multirow{10}{*}{$\begin{array}{l}\text { Frequency } \\
\text { x Doses }\end{array}$} & $1 \times 0,01$ & $-41.4 \mathrm{a}$ & $-43.8 \mathrm{a}$ & & 1 x Con. X 72 & $-62.75 b-d$ & $-90.83 \mathrm{i}-\mathrm{k}$ \\
\hline & $1 \times 0,05$ & $-46.5 \mathrm{a}$ & $-64.2 b c$ & & $2 \times 0,01 \times 72$ & $-67.84 b-e$ & $-91.50 \mathrm{i}-\mathrm{k}$ \\
\hline & 1 x Con. & $-55.3 \mathrm{ab}$ & $-67.0 \mathrm{~cd}$ & & $2 \times 0,05 \times 72$ & $-77.97 b-f$ & -80.08 h-k \\
\hline & $2 \times 0,01$ & $-48.7 \mathrm{a}$ & $-53.2 \mathrm{a}-\mathrm{c}$ & & $2 \times$ Con. $\times 72$ & $-95.71 \mathrm{f}$ & $-95.65 k$ \\
\hline & $2 \times 0,05$ & $-47.4 \mathrm{a}$ & $-51.6 a b$ & & $3 \times 0,01 \times 72$ & $-67.37 b-e$ & $-93.91 \mathrm{jk}$ \\
\hline & $2 \times$ Con. & $-66.9 b$ & $-68.8 d$ & & $3 \times 0,05 \times 72$ & $-72.56 b-f$ & -75.94 g-k \\
\hline & $3 \times 0,01$ & $-47.9 a$ & $-58.9 b c$ & & $3 \times$ Con. X 72 & -89.83 ef & $-91.37 \mathrm{i}-\mathrm{k}$ \\
\hline & $3 \times 0,05$ & $-47.2 \mathrm{a}$ & $-61.3 b c$ & & Mean & 52.02 & -58.79 \\
\hline & 3 x Con. & $-67.2 b$ & $-60.3 b c$ & & & & \\
\hline & Mean & -52.0 & -58.8 & & & & \\
\hline
\end{tabular}


salicylic acid have been reduced by the number of stone bodies (sclerotia). While low concentrations of salicylic acid have significant differences with control treatment. The application of SA is different from this study, while application of SA was sprayed on the pepper plant at the low temperature. The researcher concluded [22] that spraying plants with low concentrations of salicylic acid can stimulate endure of vital and abiotic stresses such as cold and tolerance high-temperature. This is what we applied to our effects of the salicylic acid application on cold tolerance and gene expression in pepper seedling in the test. The researchers [23]'s study showed that plants did not show a saturated seed high concentration of $1 \mathrm{mM}$ at the SA any change in tolerance iced, while the low concentrations of $0.1-0.5 \mathrm{mM}$ at the SA encouraged tolerance to sedative stress in bean and tomato.

The results of the researcher [24] were that in the low temperatures showed cultivated plants decreased by 50-70\% in the number of leaves and the length and dry weight compared to the high-temperature system. It was also shown in the cold system of plants grown an increased number of shoots in the armpits. Also, the content of proteins and chlorophyll decreased in both temperature treatments. The total nitrogen content was slightly higher at low temperatures, but nitrate was lower. These results, are like the result that we obtained from the test, and an action the researchers' studies in the field, but we used the laboratory in the test. The researchers [25] concluded that Salicylic acid increases plant's resistance to inappropriate conditions especially against the stress that is the plant is exposed to stress (saline and drought), it works on the organization of some physiological processes of plant photosynthesis and transpiration. And the results of this conformity our results in the test while we used to tolerate pepper plants for low temperatures. The found in an experiment [26] results showed the superiority of cultivated plants in the first date in plant height, the leaf area, the dry weight of vegetative total and the dry weight of root total. The superiority of plants salicylic acid treatment with $100 \mathrm{mg} / \mathrm{L}$ concentration in the leaf area, the plant height, dry weight of vegetative growth and dry weight of roots, as well as the content of roots of Arctium lappa L. plant dry weight. Aziz et al. [27] found about the response of narcissus plants to spraying with plant growth regulators salicylic acid the characteristics of the vegetative growth and syphilis and bulbs characteristics of plant daffodils. The results increased at the $80 \mathrm{mg} / \mathrm{L} \mathrm{SA}$ in the plant height, the number of branches/plant, and the ratio of chlorophyll and wet weight and flower diameter, weight wet and dry. The effect of overlap between the two studied factors is significant in most studied traits. The effect of water stress and the external application of SA on the growth and production of eggplant were investigated by Hameed et al. [28]. Results showed a significant increase for the first irrigation level W1 (water stress1) compared with level W2 (water stress2) transactions W3 (water stress3) for all indicators. Interacted treatment W1A2 (water stress $1 \mathrm{x}$ Applcation2) showed a significant increase compared with other treatments.

\section{CONCLUSION}

Three different doses of salicylic acid (SA) $(0 \mathrm{mM}, 0.01$ and $0.05 \mathrm{mM})$ were given from the leaf. Each dose was administered in three different frequencies (1 time, 2 times and 3 times spraying). Each application was exposed to cold $\left(0 \mathrm{C}^{0}\right)$ in three different times $(24 \mathrm{~h}, 48 \mathrm{~h}$ and $72 \mathrm{~h}$ ). The best dose of SA was $0.01 \mathrm{mM}$ in the Rate of Last Seedling Weight measurements, the worst result was obtained from the control group without SA treatment. Two (1 and 2 times) frequency applications applied to the seedlings exposed to low temperatures were the highest value in the Rate of Seedling Weight. Rate of Lost Seedling Lenght data, the best dose of 0.01 $\mathrm{mM}$ dose, the most appropriate frequency of applications 1 and 2 times were found to be.

\section{Acknowledgements}

The authors are grateful to the Scientific Research Projects Unit (SIÜBAP 2018-SİÜFEB-21) of Siirt University for their kind financial support. 


\section{Orcid}

\section{Zeki Karipçin (iD https://orcid.org/0000-0002-0105-6052}

\section{REFERENCES}

[1]. Mitchell, P., Moyle, J. (1967). Acid-base titration across the membrane system of rat-liver mitochondria: Catalysis by uncouplers. Biochemical Journal, 104(2), 588.

[2]. Mercado, J.A., Reid, M.S., Valpuesta, V., Quesada, M.A. (1997). Metabolic changes and susceptibility to chilling stress in Capsicum annuum plants grown at suboptimal temperature. Australian Journal of Plant Physiology, 24, 759-767.

[3]. Ansari, M.S., Misra, N. (2007). Miraculous role of salicylic acid in plant and animal system. American Journal of Plant Physiology, 2(1), 51-58.

[4]. Jabbarzadeh, Z., Khosh-Khui, M., Salehi, H. (2009). The effect of foliar-applied salicylic acid on flowering of African violet. Australian Journal of Basic and Applied Sciences, 3(4), 4693-4696.

[5]. Kling, G. J., Meyer, Jr, M.M. (1983). Effects of phenolic compounds and indoleacetic acid on adventitious root initiation in cuttings of Phaseolus aureus, Acer saccharinum, and Acer griseum. HortScience, 18, 352-354.

[6]. Shettel, N.L., Balke, N.E. (1983). Plant growth response to several allelopathic chemicals. Weed Science, 31(3), 293-298.

[7]. Ferrarese, L., Livio, M., Freedman, W., Saha, A., Stetson, P.B., Ford, H.C., Madore, B.F. (1996). Discovery of a Nova in the Virgo Galaxy M100. The Astrophysical Journal Letters, 468(2), L95.

[8]. Alvarez, M.E. (2000). Salicylic acid in the machinery of hypersensitive cell death and disease resistance. In Programmed Cell Death in Higher Plants, Springer, Dordrecht, Holland, 185-198.

[9]. Huang, Y.F., Chen, C. T., Kao, C.H. (1993). Salicylic acid inhibits the biosynthesis of ethylene in detached rice leaves. Plant Growth Regulation, 12(1-2), 79-82.

[10]. Srivastava, M.K., Dwivedi, U.N. (2000). Delayed ripening of banana fruit by salicylic acid. Plant Science, 158(1-2), 87-96.

[11]. Doares, S.H., Narváez-Vásquez, J., Conconi, A., Ryan, C.A. (1995). Salicylic acid inhibits synthesis of proteinase inhibitors in tomato leaves induced by systemin and jasmonic acid. Plant Physiology, 108(4), 1741-1746.

[12]. Ray, S. D. (1986). GA, ABA, phenol interaction in the control of growth: Phenolic compounds as effective modulators of GA-ABA interaction in radish seedlings. Biol. Planta, 28, 361-369.

[13]. Apte, P.V., Laloraya, M.M. (1982). Inhibitory action of phenolic compounds on abscisic acid-induced abscission. Journal of Experimental Botany, 33(4), 826-830.

[14]. Hayat, S., Ali, B., Ahmad, A. (2007). Salicylic acid: biosynthesis, metabolism and physiological role in plants. In: Hayat S, Ahmad A (eds) Salicylic acid: a plant hormone. Springer, Drodrecht, 1-14.

[15]. Anonymous, (2003). Siirt Tarım Master Planı. Tarım ve Köy İşleri Bakanlığı. Siirt Tarım İl Müdürlüğü.

[16]. Zielinski, M., Burke, L.A., Samokhvalov, A. (2015). Selective activation of C= C bond in sustainable phenolic compounds from lignin via photooxidation: experiment and density functional theory calculations. Photochemistry and Photobiology, 91(6), 1332-1339.

[17]. Canakci, S. (2011). Effects of salicylic acid on growth, biochemical constituents in pepper (Capsicum annuum L.) seedlings. Pakistan Journal of Biological Sciences, 14(4), 300.

[18]. Taşgin, E., Atící, Ö. Nalbantoğlu, B. (2003). Effects of salicylic acid and cold on freezing tolerance in winter wheat leaves. Plant Growth Regulation. 41(3), 231-236. 
[19]. Al-Kraidi, E.H., Al-Dulaimy, R.M. (2017). Effect of spraying with salicylic acid and boron in some yield characteristics and its components for date palm (Phoenix dactylifera L.) cvs. Zahdi and khestawi. Anbar Journal of Agricultural Sciences, 268-278.

[20]. El-Yazied, A.A. (2011). Effect of foliar application of salicylic acid and chelated zinc on growth and productivity of Sweet Pepper (Capsicum annuum L.) under autumn planting. Research Journal of Agriculture And Biological Sciences, 7(6), 423-433.

[21]. Jassim, N.S., AL-Kooranee, J.T. (2012). Effect of Salicylic acid (SA) against the fungus Macrophomina phaseolina (Tassi) Goid and development of charecoal Rot disease on Sunflower Helianthus Annuus L. Basrah Journal Agricultural Science, 25(2), 58-71.

[22]. Al-Hamdani, S.A., Al-Obeidi, Z.H., Al-Bayati, Y.Y. (2017). The effect of shading and spraying salicylic acid in 2-hoids tomato recipes by using verticai way of training method. Diyala Agricultural Sciences Journal, 9(2), 222-230.

[23]. Senaratna, T., Touchell, D., Bunn, E., Dixon, K. (2000). Acetyl salicylic acid (aspirin) and salicylic acid induce multiple stress tolerance in bean and tomato plants. Plant Growth Regulation, 30, 157-161.

[24]. Mercado, J.A., Reid, M.S., Valpuesta, V., Quesada, M.A., (1997). Metabolic changes and susceptibility to chilling stress in Capsicum annuum plants grown at suboptimal temperature. Australian Journal of Plant Physiology, 24, 759-767.

[25]. Shakirova, F.M., Sakhabutdinova, A.R., Bezrukova, M.V., Fatkhutdinova, R.A., Fatkhutdinova, D.R. (2003). Changes in the hormonal status of wheat seedlings induced by salicylic acid and salinity. Plant Science, 164(3), 317-322.

[26]. Al-Zyadi, Q.A., Mohammolad, S.O. (2018). Effect of planting date and salicylic acid spray on the growth of burdock plant (Arctium lappa L.) and its roots content of quercetin and arctiin compounds. Journal of Al-Muthanna for Agricultural Sciences, 6(1), 56-65.

[27]. Aziz, N.K., Saied, A.K.A., Edan, K.A., Ameen, S.K. (2015). Response of Narcissus plant (Narcissus poeticus) to foliar applications of plant growth regulators salicylic acid. Diyala Agricultural Sciences Journal, 7(1), 111-120.

[28]. Hameed, Z.H., Salloum, M.O., Kadhim, A.A., Fares, M.A.A. (2015). Effect of water stress and exogenous application of glycine and salicylic acid on the growth and production of eggplant (Solanum melongena L.). Anbar Journal of Agricultural Sciences, 13(2), 61-69. 